\title{
The Role of Postgraduate International Students in the Process of Internationalization of Higher Education
}

\section{Abdul Qahar Sarwari, Nubli Wahab ${ }^{a}$}

\begin{abstract}
This study was conducted to assess the role of interactions among international students from different nationalities on the process of internationalization of Malaysian higher education. An embedded design of mixed methods with the predominant role of the quantitative method was applied to conduct this study. The participants of this study were 118 international postgraduate students from a Malaysian public university, and based on their personal agreements, six of them were interviewed as well. Based on the results, the presence and persuasions of students from their countries at universities and the emerging reputation of public universities in the host country were the main reasons that encouraged international students to enroll in the university. The findings of this study also illustrated that almost all participants of this study shared some information about the quality and standards of higher education in the host country with their friends in their own countries, and encouraged some students to join the mentioned university and other universities in the country. Generally, the findings of this study confirmed the positive role of foreign students in assisting the increase in the number of international students, and also on the process of internationalization of higher education. The findings of this study may help universities to reap more benefits from their international students, and also may encourage students to have better academic achievements through their interactions with their peers from different nationalities.
\end{abstract}

KEYWORDS: Internationalization of higher education; Interactions; Collaborative learning; Global market of higher education; International students; Malaysian universities

a Center for Modern Languages and Human Sciences (CMLHS), University Malaysia Pahang (UMP), Pahang, Malaysia, Corresponding Author: Abdul Qahar Sarwari E-mail: qaharesarwari@gmail.com 


\section{Introduction}

Interactions and practices among human recourses and their good social skills play the leading role in the process of organizational transformation and globalization (Yamao \& Sekiguchi, 2015). Internationalization of higher education, transformation of the higher education norms and standards, and participation in the global market of modern education are among the national agendas of many developed and developing countries in the world. Among other emerging hubs of higher education, Malaysia as an Asian developing country aims to transform its higher education norms and partake in the global market of higher education. To achieve this goal, the Malaysian National Higher Education Strategic Plan (2004) focuses on the development of global networks of higher education, and transformation of Malaysian higher education norms through worldwide collaborative learning and educational activities. This plan also focuses on internationalization of Malaysian higher education. According to Tan \& Goh (2014), transformation of the higher education policies and landscape in the country is one of the main focusing points for the Malaysian Ministry of Higher Education to deal with the emerging worldwide challenges.

To overcome the probable challenges and open the doors to international postgraduate and postdoctoral students and researchers, the Malaysian Ministry of Higher Education (MOHE) (2012) outlined six objectives to establish research universities, and to strengthen the research based studies in the country. Based on the outlined objectives, increase of the number of international students of Malaysian public universities, especially postgraduate researchers is among the main objectives regarding the internationalization of Malaysian higher education and establishment of research universities in the country. The outlined objectives also focus on the development of research based activities, increase of economic incomes, and positive changes on the worldwide ranking of Malaysian public universities (MOHE, 2012).

The positive effects of internationalization of higher education on the social, economic and political sectors of the countries involved has encouraged Malaysia as a developing country and one of the emerging regional hubs of education to consider this issue as a national agenda. The higher education institutions and research organizations are observed as the states' instruments that could partake in the securing process of 
the financial and political situations in the country (Lee, 2008; Wang, 1992). In the age of globalization modern higher education institutions, including Malaysian universities, struggle to have more international students and derive more academic and economic benefits from them. For more than the two recent decades, the international aspects of higher education has become the core part of programs and agendas for many local governments, international organizations, universities and their related institutions and agencies (Delgado-Ma'rquez, Escudero-Torres $\&$ Hurtado-Torres, 2013). Furthermore, Kim (2010) argued that the idea of internationalization promotes special collections of people through particular policy schedules. Besides other elements and factors, foreign students of Malaysian universities may play a fruitful role in the process of internationalization of higher education in the country. According to Tan and Goh (2014), to achieve the outlined objectives of the Ministry of Higher Education, and to introduce and make the country a global hub of higher education, Malaysian universities have assumed and adopted the required strategies on recruitment of international students. It is also noticeable that foreign students who were recruited at Malaysian public universities are mostly postgraduate students (Tan \& Goh, 2014).

Based on the literature, the process of internationalization is an important issue and according to the Malaysian National Higher Education Strategic Plan (2004), participation in the global context of higher education is among the important aims of this country. The current tendency of policies in the economic and education sectors would not be understandable without the test of the appearance of the accommodating powers and their neo-liberal ideology (Kim, 2010). The role of hundreds of foreign students of Malaysian universities from different countries and different parts of the world on internationalization of Malaysian higher education was an important issue to be assessed. Moreover, there were not enough accessible works on the process of internationalization of Malaysian higher education in the literature, especially on the role of international students of Malaysian higher education institutions on the increasing number of international students in Malaysian higher education and their part in the process of internationalizing Malaysian higher education. Therefore, the major aim of this study was to assess the role of daily communication among students from different nationalities on the increase in the number of foreign students of Malaysian universities and their role in the process 
of internationalization of higher education. The findings of this study may highlight the significance of their presence on the above issue.

\section{Theoretical Framework of the Study}

Talks and negotiations about the role of globalization on the higher education sector mostly involve the features and aspects of globalization from the neo-liberal ideology and assumptions on market-directed practices which encourage people to not just consider education but also its practices (Kim, 2010). One of the ways that may enable people from different backgrounds to share their values and knowledge is daily interactions among them. The Contact Theory of Allport (1954) introduces four main steps for the process of intergroup contacts among people from different backgrounds. The proposed stages start with the sheer contact that leads into the competition, as a third step experience the accommodation and meets the last step which is assimilation. The Contact Theory was recognized among researchers and policymakers as a predominant framework when the American Supreme Court designed its famous action of integration in the Brown v. Board of Education under the theoretical guidance of this theory/hypothesis (Aidoo, 2012). According to Bourdieu (1975), the modern community and societies comprise of an array of societal fields, which include some subsystems which work under their laws and logics. Rugman and Verbeke (2004) have introduced globalization as a process which includes the improvements in the exchange of information, personnel, finance and commodities and goods across the national boundaries. Furthermore, it was argued that involvement of an organization in the process of globalization mostly engages employees in a multicultural setting of workplace (Yamao \& Sekiguchi, 2015). The previous researchers have also emphasized the effectiveness of interactions among students from different countries on their academic successes and globalization of organizations. As argued by Haneda (2014), academic interactions are useful for learning and teaching.

Interactions at the university environment are different from other locations and settings. As asserted by Chavous (2005), the collegiate environment represents a different setting and type of community. The setting is formed and perpetuated through policies, physical arrangements, 
and social standards which ease the ways for its functioning. Thus, the purposive and task-oriented contacts and interactions may be more successful in an academic setting. According to Cohen, Wildschut and Insko (2010) task-related contacts and interactions are more effective than basic interactions without task-related aims. Actually, task-related interactions make the communicators more responsive and responsible, and further the professional studies and enrolments at the modern universities in the new hubs of higher education are among the main aims that may encourage students to be involved in the daily interactions with students from different cultures and nationalities.

\section{Literature Review}

In the modern world, boundaries cannot imply everlasting lines and barriers, leastwise for the economic, linguistic and cultural intelligences (Sinicrope, Norris \& Watanabe, 2007). As stated by Coffey, Kamhawi, Fishwick and Henderson (2013), intercultural understanding and awareness are among the main requirements for the new ever-growing multicultural world, environments, and multicultural educational organizations and markets. In the $21^{\text {st }}$ century, through involvements of more countries on the process of globalization of higher education and ever-growing demands of people of different countries for professional and modern higher education, the level of enrolment of international students in the foreign countries experienced a dramatic increase. The enrolment of students at higher education institutions in foreign countries has increased dramatically since 2000 with an increase of $99 \%$, and in 2010 the number of students who were at higher education institutions outside of their own countries was about 4.1 million (OECD, 2012). The ever-growing levels of global and regional mobility of international students are the main indicators of internationalization of higher education. As stimulated by globalization, the mobility of international students is one of the main features of internationalization of post-secondary education (Tan \& Goh, 2014). Even though many other sectors were affected by financial crisis in the recent years, but the process of internationalization of higher education and mobility of international students kept continuing and as asserted by Jon, Lee and Byun (2013) whereby in spite of the global riotous and vague economy, high request for international education is kept constant. 
The continuing and stable presence of foreign students help universities to have more financial and academic opportunities, and according to Hanassab and Tidwell (2002), higher education institutions gain some financial, academic and cultural benefits from the presence of their foreign students. Nowadays, international students are the considerable parts of students of almost all modern higher education institutions throughout the world. According to Abdullah, Aziz and Ibrahim (2013), international students refer to those students who are studying abroad and holding the nationality of other countries rather than the host country.

Besides its financial benefits, the engagement of universities on the process of internationalization has direct effects on their academic and administrative affairs. As pointed out by Delgado-Ma'rquez, Escudero-Torres and Hurtado-Torres (2013), internationalization applies a controlling role on the relationships of reputations of the universities and their academic performances with the consideration of the quality of research and teaching and also employability of graduates of universities. Thus, in the new and challenging era of modern education, Malaysian universities must try to meet the requirements of their customers and international norms. As argued by Heyneman (2002), all higher education institutions in the world must meet the requirements of worldwide market of globalization. To survive and find a permanent location, higher education institutions must pay attention on the rivaling sphere of the market, and as pointed out by Mazon (2009), global competition is among the main factors which have effects on the process of internationalization. Moreover, involvements in the way of internationalization also help universities and colleges to be recognized as international organizations. As asserted by Altbach (2002), internationalization is the way that enables institutions to find their positions in the globe.

Furthermore, the ever-growing customers of higher education, helpful impacts of foreign students on the quality of higher education, and budgetary and social developments in the host countries brought some new emerging regional and global hubs and markets of higher education. As asserted by Knight (2011), the education hub is the planned efforts to establish the critical frame of regional and global performers which involved international learning, knowledge production, novel initiatives and training. Malaysia is one of these 
newly emerging Asian hubs of higher education. Prior to Malaysia, some other Asian countries such as China, India, Japan and S. Korea also were recognized as important regional hubs for Asian students and there are many other emerging educational hubs in the region. The regional hubs of higher education are emerging in Asia, especially in the East Asia and it illustrates the high request for internationalization of higher education (Jon, Lee \& Byun, 2013). Some Asian countries like $\mathrm{S}$. Korea have already launched many encouraging programs to grab the attention of international students and become active member of global market of higher education. From the beginning of the 20th century, many large-scale initiatives were launched by the Korean government to considerably increase the enrolments of international students at the Korean higher education institutions (Byun \& Kim, 2011).

Actually good agendas and plans are helpful, but more attentions on the factors and agents that affect and help the process of internationalization of higher education would be more fruitful. A multicultural aspect of education requires the ideas, reform of the educational norms, and practice of deferential intergroup and multicultural dialogues, self-awareness and being open to the others (Banks \& McGee, 2001). Besides other main factors that affect the process of internationalization of higher education, the evolution of the role of those international students who are already enrolled at the universities may help institutions to focus on their foreign students as real and free agents of internationalization of higher education.

\section{Methodology}

An embedded design of mixed methods was applied to conduct this study. The quantitative survey through direct distribution of the questionnaires was applied as the predominant method of this study and the qualitative data through the direct and audio-taped interviews were collected and embedded into the quantitative data to enrich the information. As asserted by Creswell and Plano Clark (2007), during their studies researchers use the embedded method when they need to encompass the two methods to find answer(s) of their question(s) with more details. 


\section{Participants}

Participants of this study were $118(M=96.8, S D=13)$ international students of a Malaysian public university from 16 different countries. According to the demographic information, the vast majority of the participants (88.2) were from male, and almost half (48.2\%) of them were under the age category of 23-29, and the majority of them were postgraduate students. All participants of this study belonged to 16 different countries, and also six postgraduate students from six different countries were interviewed for the qualitative section of this study. According to Creswell and Plano Clark (2007), through a survey instrument, researchers collect the quantitative data and to deepen their survey results, they conduct the interviews from few of the participants of their survey. Table 1 below illustrates the frequencies of participants of both quantitative and qualitative sections based on their countries.

Table 1: Frequency of survey participants and interviewees based on their countries

\begin{tabular}{lcc}
\hline Country & $\begin{array}{c}\text { Frequency of } \\
\text { Survey Participants }\end{array}$ & $\begin{array}{c}\text { Frequency of Interview- } \\
\text { ees }\end{array}$ \\
\hline 1. China & 18 & 1 \\
2. Indonesia & 13 & 0 \\
3. Iraq & 13 & 1 \\
4. Yemen & 13 & 0 \\
5. India & 12 & 0 \\
6. Afghanistan & 10 & 0 \\
7. Pakistan & 9 & 1 \\
8. Bangladesh & 6 & 0 \\
9. Libya & 6 & 0 \\
10. Nigeria & 5 & 1 \\
11. Sudan & 4 & 1 \\
12. Algeria & 3 & 1 \\
13. Egypt & 2 & 0 \\
14. Canada & 1 & 0 \\
15. Somalia & 1 & 0 \\
16. Iran & 1 & 0 \\
\hline
\end{tabular}




\section{Instruments}

The main instrument for the quantitative section of this study was a revised version of the Interpersonal Competence Questionnaire (ICQ) of Buhrmester, Furman and Wittenberg (1988). The revised version of ICQ included 29 items and each item had 5options based on the Likert scale from (Strongly Agree) to (Strongly Disagree). For the qualitative data collection procedure, an interview protocol which was adapted from Trilokekar (2007) and included eight open ended questions was applied. According to Slavin (2007), the instrument for the qualitative interviews can include unstructured questions. Furthermore, prior to the process of data collection, the instruments were checked and fixed through a pilot test. As argued by Slavin (2007), pilot test works as an experimental run for the study and helps the researchers to check their instruments and identify its problems to address prior to the process of the real data collection. Based on the reliability test, Cronbach's alpha rating for the data was .85 .

\section{Data Collection and Data Analysis Procedures}

The population of this study was all postgraduate students of a Malaysian public university, which had 460 international postgraduate students from 21 different countries in the 2014/2015 academic year. Both of the quantitative and the qualitative data were collected directly. The convenience data collection method was applied for the quantitative data and all interviews were conducted directly and audio taped. The quantitative data were examined through the required options of SPSS. The descriptive test was applied to find out the frequencies and percentages of demographic information, and the level of agreements of participants with the items (questions). The qualitative interviews were analyzed separately, and the findings were divided into their related themes and categorizes. As asserted by Wiersma and Jurs (2005), generally, results of a survey are stated in the descriptive mode, but other analyses and opportunities also applicable to serve the aim of the study. 


\section{FINDINGS}

\section{Quantitative Findings}

The descriptive test of SPSS was applied to find out the demographic information and also the frequencies and percentages of participants' agreements with the items. Based on the descriptive results, this study had 118 participants from international students of a Malaysian public university. The overall Mean score of the participant for all items together was 96.8, and their St. Deviation score was $=13$. As the instrument included 29 items and each item had five options, thus the highest estimated score was 145 , and the average score was 72.5. As the overall mean score of the participants was 96.8 and it is higher than the average mean score. Thus, it shows a positive situation of interactions among the participants.

Moreover, based on the results of the descriptive test, the vast majority of the participants agreed with the items and the level of their agreements was strongly supportive of the positive effects of presence of foreign students on the process of internationalization of Malaysian higher education and establishment of educational networks among people of different nationalities. From all 118 participants of this study, $52(44 \%)$ of them agreed that they joined the university because of its good reputation and academic quality, $56(47.4 \%)$ of them reported that their relations with the university students from their countries who joined the university prior to them was one of the main causes to enroll in this university. Furthermore, $48(40.6 \%)$ of the participants reported that the western countries recent visa and trip limitations for people of the middle-east, south-Asia and some African countries were the main reasons to choose Malaysia as an alternative education hub.

From all 118 participants of this study, 87 (73.7\%) of them reported that their interactions helped them to have more collaborative activities with their peers from different countries, $79(73.6 \%)$ of them reported that they interact with their classmates regardless of their nationalities. From all participants, 77 (65.2\%) of them reported that when they joined the university encouraged other students from their countries to join the same or other Malaysian universities. Furthermore, 94 (79.6\%) of them reported that they will transfer some useful experiences gained from Malaysian higher education norms and standards to their own countries. 


\section{Qualitative Findings}

The qualitative section of this study had six interviewees from six different countries. Interviewees were: Participant 1 , a $\mathrm{PhD}$ student from India, participant 2, a Master student from Afghanistan, participant 3, a $\mathrm{PhD}$ student from Algeria, participant 4, a Master student from Nigeria, participant 5, a Master student from China and participant 6 was a Master student from Yemen. The findings of the quantitative section are categorized into two main themes and categories, as 1) Internationalization of Higher Education and 2) Collaborative Learning among Students from Different Nationalities. In the qualitative results, instead of writing participant, just the letter ' $\mathrm{P}$ ' and the given number of participant will be mentioned. For example, P1 comes instead of participant number 1 .

\section{Internationalization of higher education}

For this section, the answers of almost all interviewees illustrated that the presence of foreign students at the university campus had positive effects on increase of the number of foreign students at the university, the reputation of the mentioned university and other Malaysian universities among other people. For instance, P3 stated that "When I came to the university, I was the only student from Algeria and through my contacts with some of my friends and the people who had contacts with me, the number of Algerian students increased." Also according to him "As Malaysian universities are well-equipped and have better academic situations rather than our [Algerian] universities and follow the main education standards of some developed countries like England, thus many students like to join these universities". Another interviewee, P1 also said that "Daily interactions among international and local students help both local and international students to discuss their education norms, especially when local students ask foreigners that why they came to Malaysia. They described the reasons and the differences among their teaching methods and universities." According to this point of view, both local and international students in the university campus are interested to talk about their educational norms and it may be one of the ways of integrating these different educational norms.

P6 stated that "At first there were just three Yemeni students at the university until 2012, but because of their encouragements and negotiations with other Yemeni students, now the number of students 
from Yemen at the same Malaysian university is around 40 and still increasing." Also as he pointed out, "Malaysian universities are the only place for some conservative Yemeni families to send their daughters [female students] to study the modern sciences like engineering and computer sciences" as told by P6. Their points of views were clearly supportive of the quantitative findings of this study, and also show the positive role of foreign students on internationalization of Malaysian higher education.

\section{Collaborative learning among students from different nationalities}

Almost all of the interviewees reported that they had some collaborative activities and university related team works with their counterparts from different nationalities at the university campus. As the interviewee P4 said "I am doing my master by coursework and many Malaysian students join our classes and courses. We discuss and do our assignments together and we also discuss and help our friends through internet, we also discuss anytime we want." His views were supported by P2 who said "I always interact with local and international students of the university and try to learn some new things from them. Mostly, I solve the problems of my study with the help of other students and I can meet other students in the cafeteria and everywhere at the university." Another participant also said that "Actually, we live in a multicultural campus and we can interact with people of different social backgrounds and ethnicities. We also join in some social and cultural activities in the hostel and at the university campus" as asserted by P1.

Finally, P5 told that "I have very important experience from my contacts with other students and learned many things from them. When I came from China, I was not able to speak English and could not understand my daily homework and activities which belonged to a different method of education, but by the help of local students, especially Chinese-Malaysians and other international students I learned everything and now I am very happy with my university campus life." The mentioned statements confirmed that gatherings of students from different nationalities at the collegiate campus had positive effects on the level collaborative activities among them, and also paved the ways for the establishments of multinational networks of education. The mentioned assertions are also supportive of the positive role of interactions among students from different nationalities in a multicultural 
collegiate environment on the process of internationalization of higher education and increase of collaborative activities among them.

\section{DISCUSSION}

This study was conducted to assess the role of interactions among international postgraduate students of a Malaysian public university on the process of internationalization of higher education in the country. Based on the information of OECD (2012), the mobility and enrolment of international students in the foreign countries experienced a dramatic increase since the year 2000, and mostly students prefer to study in these regional hubs. Under the guidance of the six outlined objectives of the Malaysian Ministry of Higher Education on development of research-based studies and increase of international students (MOHE 2012), Malaysian universities have also established their programs to bring positive changes in the number and eligibility of their international students. It was important to consider the helpful role of international students on easing the ways for Malaysian universities to achieve their projected goals; thus this study was conducted. The results of this study confirmed that the presence of foreign students in Malaysian universities was helpful in the process of internationalization of higher education. Based on the findings, foreign students had positive role on the popularity of Malaysian universities among other people, especially in their own countries.

The results also confirmed that foreign students played a significant role in the increase of the number of international students of the mentioned Malaysian public university and other Malaysian universities. As argued by Hanassab and Tidwell (2002), universities gain some significant advantages from existence, educational, cultural and economic contributions of foreign students. This argument was supported by findings of the current study. According to the quantitative findings of this study, the vast majority of participants agreed that their discussions with students from different nationalities paved the ways for them to talk about their educational norms and exchange their personal experiences. They have also reported that their talks with other students improved their personal and academic lives.

The results from this study also identified the three main reasons that encourage some international students to choose Malaysia instead of other countries, especially western countries as the traditional 
hubs of higher education for foreign students. The first reason which encouraged international students of the university was the presence of students from their countries and nationalities at the university and other Malaysian universities and their encouraging advices. The second reason was the emerging reputation and academic quality of Malaysian universities, and the third reason was some problems and trip limitations for the people of some Asian and African countries in the western parts of the world. Thus, the regional mobility and recruitments of foreign students increased rather than global mobility (OECD, 2011).

The qualitative findings of this study were also supportive of the quantitative results and almost all interviewees through their direct views confirmed that they played the role of unofficial and unpaid agents of internationalization of Malaysian higher education. Their points of views also described that they encouraged other foreign students to join the university and or some other Malaysian universities. Other Malaysian universities and colleges also may take the same benefits from their international students. Thus, this issue guarantees an argument on the positive role of foreign students of Malaysian higher education institutions on the process of internationalization of Malaysian higher education. The findings of this study also confirmed the existence of collaborative activities among students of different nationalities at the university campus.

Almost all of the findings of this study on the role of foreign students of Malaysian universities and on the process of internationalization of Malaysian higher education are new because there were insufficient accessible studies on the same or the related issues in the literature. The findings of this study may ease the ways for Malaysian higher education institutions to reap benefits from their international students in the way of internationalization of higher education.

\section{RECOMMENDATIONS}

Internationalization of higher education would remain as an important and interesting issue for researchers in Malaysia and many other countries in the future. Therefore, researchers can evaluate the role of academic quality and learning opportunities at university campuses on the process of internationalization of higher education. The role of educators and academic staff of modern universities on the above mentioned 
process also can be an interesting issue for the future researchers. As transformation of higher education norms is important for the process of internationalization of higher education, future researchers can evaluate the role of international students on the process of transformation of higher education norms in the host countries.

\section{CONCLUSION}

This study was undertaken to examine the role of interactions among postgraduate students from different countries and cultural backgrounds in bringing more international students into Malaysian public universities, and their effectiveness on the process of internationalizations of Malaysian higher education. The findings of this study confirmed that students from different nationalities and cultural backgrounds played positive roles in the increase of the number of foreign students and exchange of information about different norms of higher education with students from different countries. According to the results, positive encouragement from students from their own countries who studied at Malaysian higher education institutions, good standings of universities in the host country, and some trip limitations for people of some Asian and African countries in the western parts of the world were the main reasons that encouraged international students to enroll in the university. The results of this study confirmed the positive role of foreign students on the process of internationalization of higher education. The findings of this study may help universities to take more benefits from their international students and achieve their projected aims. Further studies in the future may answer more questions on the related issues.

\section{Acknowledgements}

This study was conducted by the financial sponsorship of University Malaysia Pahang (UMP) under the Doctoral Scholarship Scheme (DSS). 


\section{References}

Abdullah, D., Abd Aziz, M. I., \& Mohd Ibrahim, A. L. (2013). A "research" into international student-related research: (Re)Visualising our stand?. Higher Education, 67, 235-253.

Aidoo, B. (2012). An examination of mature interpersonal relationships among international and American college students ( Doctoral dissertation). Available from ProQuest Dissertations \& Theses database. (UMI No.3534803).

Allport, G. W. (1954). The nature of prejudice. Cambridge, MA: Perseus Books.

Altbach, P.G. (2002). Perspectives on internationalizing higher education. International Higher Education. Retrieved from http://www.bc.edu/bc org/avp/soe/cihe/newsletter/News27/text004.htm

Banks, C. A., \& McGee Banks, C. A. (Eds.). (2001). Multicultural education: Issues and per spectives. Boston: Allyn and Bacon.

Bourdieu, P. (1975). The specificity of the scientific field and the social conditions of the progress of reason.Social Science Information, 14, 1947.

Buhrmester, D., Furman, W., \& Wittenberg, M. (1988). Five domains of interpersonal competence in peer relationships. Journal of Personality and Social Psychology, 55, 991-1008.

Byun, K., \& Kim, M. J. (2011). Shifting patterns of the government's policies for internationalization of Korean higher education. Journal of Studies in International Education, 15(5), 467-486.

Chavous, T. M. (2005). An intergroup contact-theory framework for evaluating racial climate on predominantly white college campuses. American Journal of Community Psychology, 36 (3/4), (239-257).

Coffey, A. J., Kamhawi, R., Fishwick, R., \& Henderson, J. (2013). New media environments' comparative effects upon intercultural sensitivity: A fivedimensional analysis. International Journal of Intercultural Relations; 37, $605-627$

Cohen, T. R., Wildschut, T., \& Insko, C. A. (2010). How communication increases interpersonal cooperation in mixed-motive situations. Journal of Experimental Social Psychology, 46, 39-50.

Creswell, J. W. \& Plano Clark, V. L. (2007). Designing and conducting mixed methods research. Thousand Oaks, CA: Sage.

Delgado-Marquez, B. L., Escudero-Torres, M. A., \& Hurtado-Torres, N. E. (2013). Being highly internationalized strengthens your reputation: 
an empirical investigation of top higher education institutions. Higher Education, 66, 619-633. doi: 10.1007/s10734-013-9626-8.

Hanassab, S., \& Tidwell, R. (2002). International students in higher education: Identification of needs and implications for policy and practice. Journal of Studies in International Education, 6(4), 305-322.

Haneda, M. (2008). Contexts for learning: English language learners in a

US middle school. International Journal of Bilingual Education and Bilingualism, 11(1), 57-74.

Heyneman, S. (2002). International education. Encyclopedia of Education, 4(2), 1265-1276.

Jon, J. E., Lee, J. J., \& Byun, K. (2013). The emergence of a regional hub: comparing international student choices and experiences in South Korea. Higher Education, 67, 691-710.

Kementerian Pengajian Tinggi (KPT) (Ministry of Higher Education, MOHE) (2012). Instrument Malaysia Research Assessment (MyRA). Retrieved October 12, 2012 from http://jpt.mohe.gov.my/IPT/MyRA.php.

Kim, E.Y. (2010). Internationalization of Korean higher education. (Doctoral dissertation), Available from ProQuest Dissertations \& Theses database. ( UMI No. 3425397 )

Knight, J. (2011). Three types of educational hubs: Student, talent and knowledge: Are indicators useful or feasible? The Observatory on Borderless Higher Education. October, 2011.

Lee, E. (2008). Singapore: The unexpected nation. Singapore: Institute of Southeast Asian Studies.

Malaysian National Higher Education Strategic Plan (2004). Official website of the Ministry of Higher Education Malaysia: (http://jpt.mohe.gov.my/ eng/index.php?)

Mazon, B. K. (2009). The student experience of internationalization in a u.s. and dutchhigher education context (Doctoral dissertation). Available from ProQuest Dissertations \& Theses database. (UMI No. 3391059).

Organisation for Economic Co-operation and Development (OECD) (2011). Education at a Glance 2011:OECD Indicators. Organisation for Economic Co-operation and Development. Retrieved October 30, 2011 www.oecd. org/edu/eag2011.

Organisation for Economic Co-operation and Development (OECD). (2012). Education at a Glance 2012:OECD Indicators. Organisation for Economic Co-operation and Development. 
Rugman, A. M., \& Verbeke, A. (2004). A perspective on regional and global strategies of multinational enterprises. Journal of International Business Studies, 35(1): 3-18.

Sinicrope, C, Norris, J., \& Watanabe, J. (2007). Understanding and Assessing Intercultural Competence: A Summary of Theory, Reseach, and Practice (Technical Report for the Foreign Language Program Evaluation Project). Second Language Studies, 26 (1), 1-58.

Slavin, R. E. (2007). Educational Research in an Age of Accountability. Boston: Pearson.

Tan, Y. S., \& Goh, S. K. (2014). International students, academic publications and world univer sity rankings: the impact of globalization and responses of a Malaysian public university. Higher Education.

Trilokekar, R. D. (2007). Federalism, Foreign Policy and the Internationalization of Higher Education: A Case Study of the International Academic Relations Division, Department of Foreign Affairs and International Trade, Canada (Doctoral Dissertation). University of Toronto: Canada.

Wang, G. (1992). Universities in transition in Asia. Oxford Review of Education, 18(1), 17-27.

Wiersma, W. \& Jurs, S. G. (2005). Research methods in education ( $8^{\text {th }}$ ed.). Boston, MA: Pearson Education.

Yamao, S. \& Sekiguchi, T. (2015). Employee commitment to corporate globalization: The role of English language proficiency and human resource practices. Journal of World Business, 50, 168-179. 